\title{
Environmental and cost life cycle analysis of the impact of using solar systems in energy renovation of Southern European single-family buildings
}

\author{
Ricardo Mateus*, Sandra Monteiro Silva, Manuela Guedes de Almeida \\ Centre for Territory, Environment, and Construction (CTAC), University of Minho, Campus de Azurém, 4800-058 Guimarães, Portugal
}

\section{A R T I C L E I N F O}

\section{Article history:}

Received 4 August 2017

Received in revised form 7 March 2018

Accepted 9 April 2018

Available online $\mathrm{xxx}$

\section{Keywords:}

Solar systems

Energy renovation strategies

nZEB

ZEB

LCA

\begin{abstract}
A B S T R A C T
Nowadays, in the European Union (EU) the construction rate of new buildings is very low and therefore achieving the EU targets regarding the energy efficiency of the building sector is only possible through the reduction of the energy needs of the existing building stock. A building design based on passive measures is a priority to reduce operational energy consumption but it is not enough to achieve the nearly Zero Energy Building (nZEB) level. Consequently, the design must also consider active systems with high efficiency and the use of renewable energy sources to partially/totally replace the use of nonrenewable energy. At this level, solar thermal and photovoltaic panels play an important role, mainly in countries with high levels of solar radiation, as in the Southern European countries. Nevertheless, there are still some barriers to overcome for the broader dissemination of the implementation of these systems. One of the most important is that building owners are not fully aware of the life cycle benefits that these systems have at environmental and economic levels. The best way to raise awareness to these benefits is through the analysis of case studies, highlighting the short or mid-term benefits resulting from the integration of these active solutions. Thus, this paper is aimed at analysing the environmental and life cycle costs of different energy renovation scenarios, assessing the contribution of the solar systems to achieve three levels of energy performance. The study is focused on the energy renovation of a detached single-family house considering the climatic conditions of Porto, Portugal. From the results, it is possible to conclude that, on an annual basis, and for the Portuguese climate, it is possible to overcome, many of the energy needs for acclimatization and preparation of domestic hot water with the integration of these systems. The study also shows attractive economic and carbon payback times resulting from their use.
\end{abstract}

๑) 2018 Elsevier Ltd. All rights reserved.

\section{Introduction}

During the different life cycle stages, a building consumes a great amount of energy. It includes the embodied energy, i.e. the energy required for the production and transport of building products and systems; the operational energy used for Heating, Ventilation and Air Conditioning (HVAC) systems, lighting and production of Domestic Hot Water (DHW); and the energy related with the building demolishing/dismantling and final waste treatment at the end-of-life stage.

Buildings are responsible for $30-40 \%$ of the primary energy

\footnotetext{
* Corresponding author.

E-mail address: ricardomateus@civil.uminho.pt (R. Mateus).
}

consumption and approximately $33 \%$ of greenhouse (GHG) emissions worldwide [1]. At the European Union, building sector, in general, is responsible for around $40 \%$ of the energy consumption and about $32 \%$ of the carbon emissions [2]. The breakdown of fossil fuels and the potential environmental impacts caused by the related greenhouse gas emissions is nowadays one of the biggest worldwide concerns that are increasing the debate and research around the reduction of energy consumption [3].

Residential buildings represent $25 \%$ of the total energy consumption in Europe, being an important target for policies aiming at improving the energy efficiency and reducing the carbon emissions [4]. The potential of emissions mitigation in this sector is relevant and as much as $80 \%$ of the operational costs of standard new buildings can be saved through integrated design principles, often at no (or little) extra cost over the lifetime of the measure [3]. 
The energy context in Portugal shows that the residential sector is a major consumer of energy, being responsible for around $20 \%$ of the total primary energy consumption, $39.1 \%$ of it is used for the kitchen, $23.5 \%$ for the preparation of DHW, 21.5\% for space heating, $10.9 \%$ for appliances, $4.5 \%$ for lighting and $0.5 \%$ for space cooling [5].

Improving the buildings' energy performance is thus an important part of the European Union (EU) 2020 and 2030 energy targets as well as of the roadmap for moving towards a competitive low carbon economy in 2050 [[6-8]]. The targets defined for 2020 are $20 \%$ reduction in energy consumption, $20 \%$ reduction in carbon emissions and $20 \%$ increase in renewable energy use [6]. The EU framework on climate and energy for 2030 is committed to reducing, until 2030, EU domestic carbon emissions by $40 \%$ when compared with the 1990 level and 25\% reduction in energy consumption [8]. This target will ensure that EU is the cost-effective track towards meeting its objective of cutting emissions by at least $80 \%$ by 2050 [7]. The Commission also proposes an objective of increasing the share of renewable energy to at least 27\% of the EU's energy consumption by 2030 [8].

Additionally, according to the EPBD-recast, all EU Member States shall ensure that by 31 December 2020 (31 December 2018 for occupied and owned by public authorities) all new buildings are nearly Zero Energy Buildings (nZEB), that is a building with a very high energy performance and the nearly zero or very low amount of energy required should be significantly covered by energy from renewable sources, preferably produced on-site or nearby [6]. The EPBD-recast also requires that buildings have to be cost-effective during their life cycle and establishes a methodology for costoptimal calculations.

Therefore to meet EU targets for the building sector it is necessary to implement cost-effective strategies for increased efficiency and deployment of renewable energy to achieve the best building performance (e.g. less energy use, fewer carbon emissions and higher co-benefits related to indoor environmental quality) at the lowest possible effort (e.g. initial costs, life cycle costs and occupant's disturbance in the case of building renovation).

The nearly Zero Energy Building (nZEB) performance is achieved by reducing the buildings' energy needs, through passive approaches (e.g. improving insulation levels, optimizing solar gains and external solar shading systems and night cooling); selecting efficient appliances and systems (e.g. lighting, heating, cooling, and ventilation systems); and on-site production of renewable energy to reduce the remaining non-renewable energy use. Solar thermal and photovoltaic systems together with biomass and geothermal energy sources are the most common energy sources used in buildings.

To achieve the defined targets, it is necessary to improve the performance of the existing building stock due to its representativeness in the overall building stock and poor energy performance. Additionally, the small rate of new building construction in Europe (1-2\% per year) makes energy savings insignificant if the focus is only on new building construction [9].

The renovation of existing buildings is an opportunity to improve their energy performance that is many times missed. The two main barriers to the dissemination of energy renovation of buildings are the high initial costs and the lack of know-how and awareness regarding the cost-effectiveness of the energy retrofit measures [10], especially if a life cycle cost approach is not considered and co-benefits of energy retrofit measures are ignored. Co-benefits of retrofit measures beyond energy savings include lower noise levels and improved comfort from insulation and glazing, better indoor air quality and temperature control from new HVAC systems, less operational maintenance or increased energy security against energy price fluctuations by the deployment of renewable energy resources [3]. After reducing the energy losses and controlling the unwanted heat gains it is necessary to use renewable energy systems to supply the remaining, very low, energy needs of the building.

The sustainable building plays a crucial role in reaching the EU's long-term 80-95\% GHG reduction objective and also plays an important role in the European economy [11]. Sustainability takes into account the entire life cycle of the building, from design to construction, operation, maintenance, renovation, and demolition, and it aims to find the right balance between built environment and the natural one [12]. Every year new technologies are developed to complement current practices in creating more sustainable buildings trying to create exceptional indoor environments for building occupants while reducing the potential impacts on the natural environment.

Several studies were performed worldwide to assess the life cycle costs and life cycle savings of different types of solar thermal and photovoltaic systems [13-20] and for other energy sources [21-23]. Solar systems (solar thermal - STC, photovoltaic - PV, and hybrid photovoltaic-thermal - PVT) show to be effective in reducing the whole buildings' life cycle impacts [24]. Additionally, they do not produce noise, do not have an impact on birds as the wind turbines, and are, in general, easier to install than ground source heat pumps, which require the use of buried ground pipes, are reliable and have lower maintenance costs [24].

The main disadvantages of solar energy are the initial cost of the systems, the intermittency, and unpredictability, availability of sunlight during daytime only and the dependence on the local climate conditions [25]. Additionally, these systems require a significant amount of space and some roofs are not large enough to encompass the number of solar panels necessary to meet the building energy needs (thermal and electricity) and the installation on the facades can also be limited due to shading produced by surrounding buildings or due to local restrictions. The use of PVT solar systems can simultaneously provide electricity and heat, needing less space and achieving a higher conversion rate of the absorbed solar radiation than standard PV modules [26]. PV systems are more expensive and are less efficient than STC, being the initial costs a major barrier to the installation of these systems buildings [27-29]. It is also necessary to consider the potential environmental impacts related to the manufacture, transportation and maintenance and the environmental benefits related to the energy savings of the solar systems [24].

At the moment there is only a qualitative definition of a nZEB in Portugal. According to the Portuguese thermal regulation [30], a nZEB is a building with a high energy performance, where the energy required should be covered to a very significant extent by energy from renewable sources, mainly produced on-site or nearby. To achieve this goal, the thermal regulation also set that a nZEB building should be designed to use cost-optimal solutions for the envelope [30]. Some studies, such as [31] were developed to define the nZEB numerical threshold but concluded that the cost-optimal solutions have a great variation, according to the characteristics of the buildings and the climate zones, indicating difficulties to the establishment of a numerical indicator of primary energy use for the nZEB energy performance level in Portugal. These studies also concluded that for building renovation, the cost-optimal renovation scenario allows around 80\% energy savings when compared with a scenario that fulfils the minimum national energy performance requirements [31-33]. In Portugal, the method to quantify the energy performance of a residential building only includes the energy for heating, cooling and production of DHW. Therefore, other types of energy consumptions are excluded from the energy balances calculated in these studies.

In this context, the aim of this paper is to analyse and compare the life cycle performance of three energy renovation scenarios 
(Basic, Cost-optimal and Zero Energy) for a Portuguese singlefamily residential building and to compare it with the existing building (Maintenance or Before Renovation) scenario. For the energy certification of residential buildings, according to the Portuguese thermal regulation [30], the methodology to estimate the building's energy needs and their comparison with the national reference values are based on the energy consumption for heating, cooling and DHW preparation. Therefore, other types of energy consumption are not included in this study.

In the Maintenance scenario only maintenance works are carried out, and therefore the thermal performance of the building is not improved. The Basic scenario corresponds to the adoption of energy renovation principles that meet the minimum energy requirements of the Portuguese thermal regulation [30]. The Costoptimal scenario corresponds to a cost-optimal renovation scenario, according to the methodology of the EPBD recast [6]. For Portugal, this means a renovation scenario with around $80 \%$ energy savings compared with a scenario that fulfils the minimum energy requirements [34]. The Zero Energy is a scenario where the nonrenewable energy used in the cost-optimal renovation scenario for HVAC and DHW is compensated by the on-site harvested energy from renewables. The analysis is focused on the contribution of the solar systems to the increased costs and environmental impacts during the renovation works and its reduction during the operation phase.

For each renovation scenario, the economic payback time and greenhouse emissions payback time for the materials and systems used were assessed. To study the efficiency of each renovation scenario the paper presents the calculation of the lifetime costs and energy consumption using the Portuguese thermal regulation methodology. Additionally, the payback time of the renewable energy systems was also estimated.

A typical Portuguese detached single-family building, that is representative of the Portuguese multifamily housing stock built between 1961 and 1990, that represents 44.5\% of the total Portuguese residential building stock [35], was chosen for this study.

\section{Case study}

In this study, a typical Portuguese residential building is analysed. The building studied is a virtual building, which characteristics were defined based on the building stock built in Portugal in the period bounded between 1961 and 1990. The buildings built in these decades represent 44.5\% of the buildings built until 2011 (last available data) [35]. For the calculations, Porto's climatic conditions were considered.

The case study is a detached single-family house, with two floors (the garage is located on the ground floor and the residential area is located on the first floor), $100 \mathrm{~m}^{2}$ of net area, $2.7 \mathrm{~m}$ floor to ceiling height, $15 \mathrm{~m}^{2}$ of windows, equally distributed among the four façades, and three bedrooms. Its main facades are oriented to the north and south. It has a reinforced concrete structure and there is no insulation in the building envelope, as it was the common practice at the time. The exterior walls are $22 \mathrm{~cm}$ thick hollow brick walls with render on both inside and outside surfaces; the windows are single glazed with aluminium frames; the floors are beam and pot slabs with $15 \mathrm{~cm}$ thick; the roof is pitched with ceramic roof tiles. The building has a gas heater for the production of DHW (efficiency of 0.89 ) and there are no central heating or cooling systems, which is the common situation in this type of buildings (usually portable electric heaters and fan coils are used) [35].

In the Maintenance scenario, the thermal performance of the building is not improved, only maintenance works are carried out. The maintenance works include the repair of cracks, cleaning and painting of the façade, replacement of radiators, fan coils and gas heater for equivalent ones.

In the Basic renovation, an External Thermal Insulation Composite Systems (ETICS) system is used, with $5 \mathrm{~cm}$ of XPS, to retrofit the façade walls. The existing windows were replaced by double glass windows with PVC frame. Additionally, an XPS board $(7 \mathrm{~cm}$ thick) was placed under the first floor (in the garage ceiling) and over the ceiling (on the attic floor). The roof tiles were also replaced. The radiators and gas heater were replaced by new ones and a cooling system (a chiller) was installed. For the production of DHW a flat plate solar collector (the reference system defined in the Portuguese Thermal Regulation [36]), a 160 L storage tank and a gas heater as a backup system were installed.

In the Cost-optimal and Zero Energy renovation, the passive solutions, i.e. those implemented in the envelope, are the same as the ones in the Basic solution. In these scenarios, an HVAC system (multi-split), for heating and cooling was considered. A vacuum tube collector, with a $260 \mathrm{~L}$ storage tank, ensures the production of DHW and a heat pump is used as a backup system. In the Zero Energy scenario, a PV system $\left(12.9 \mathrm{~m}^{2}\right.$ of polycrystalline panels with a total nominal power of $1.8 \mathrm{kWp}$ ) was also installed.

The properties of the building considered in each scenario are shown in Table 1 . The air change rates were calculated using the methodology defined in the Portuguese thermal regulation [30]. The reduction of the air change rates in the renovation scenarios is due to the replacement of the existing windows by new more airtight ones.

\section{Research methodology}

The methodology is based on the analysis, for each scenario, of the: i) operational energy for heating, cooling, and production of DHW; ii) life cycle impacts, using a standardized LCA method (EN 15978:2012 [37]); iii) economic payback time (EPBT); and carbon emissions payback time (GPBT). For the calculation of the energy needs the methodology of the Portuguese thermal regulation for residential buildings was followed [30], which is based on the quasi-steady state method presented in ISO 13790:2008 [38].

\subsection{Assessment of the energy performance}

The Portuguese thermal regulation provides the values of the degree-days and uses the envelope heat balance method for the calculation of heating needs. With regard to cooling needs, it uses the average difference between indoor-outdoor temperature and the envelope heat balance during the cooling period. The indoor conditions considered for the heat balance are an absolute minimum of $18{ }^{\circ} \mathrm{C}$ for air temperature in winter and an absolute maximum of $25^{\circ} \mathrm{C}$ for air temperature and $50 \%$ for relative humidity in summer, in accordance with the Portuguese thermal performance of residential buildings regulation [30].

The energy used for Domestic Hot Water production was calculated according to the reference DHW consumption [30]: $40 \mathrm{~L}$ per person and per day, heated at $50^{\circ} \mathrm{C}$. In the methodology, the internal load for people, lighting, appliances, and equipment considered is $4 \mathrm{~W} / \mathrm{m}^{2}$ [30]. The energy necessary for lighting and appliances is not considered in this methodology.

The contribution of the solar thermal energy was calculated using the SCE.ER software [39]. This software implements the official methodology of the national thermal regulation [30]. The calculation of the electricity produced by the PV system was based on the European Commission's Photovoltaic Geographical Information System (PVGIS) [40], considering the building's location (Porto, 41.18N, 8.68 E) and the characteristics of the PV system used.

The primary energy was calculated considering the conversion factors of $2.5 \mathrm{kWh}_{\mathrm{PE}} / \mathrm{kWh}$ for electricity and $1 \mathrm{kWh} / \mathrm{PE} / \mathrm{kh}$ for 
Table 1

Properties of the building before and after each of the renovation scenarios.

\begin{tabular}{|c|c|c|c|c|}
\hline Properties of building & $\begin{array}{l}\text { Before renovation } \\
\text { (Maintenance) }\end{array}$ & $\begin{array}{l}\text { Basic renovation } \\
\text { (minimum legal requirements) }\end{array}$ & Cost-optimal renovation & Zero Energy renovation \\
\hline \multicolumn{5}{|l|}{ Thermal transmittance, $\mathrm{W} /\left(\mathrm{m}^{2} \cdot \mathrm{K}\right)$} \\
\hline$U_{\text {wall }}$ & 1.76 & 0.47 & 0.47 & 0.47 \\
\hline$U_{\text {roof }}$ & 2.80 & 0.35 & 0.35 & 0.35 \\
\hline$U_{\text {floor }}$ & 2.10 & 0.39 & 0.39 & 0.39 \\
\hline$U_{\text {window (glass/frame) }}$ & 4.10 & 2.70 & 2.70 & 2.70 \\
\hline$U_{\text {door }}$ & 2.31 & 0.49 & 0.49 & 0.49 \\
\hline \multicolumn{5}{|l|}{ Linear thermal transmittance, $\mathrm{W} /(\mathrm{m} \cdot \mathrm{K})$} \\
\hline$\neg$ wall/wall & 0.50 & 0.40 & 0.40 & 0.40 \\
\hline$\neg$ roof/wall & 0.70 & 0.70 & 0.70 & 0.70 \\
\hline$\neg$ floor/wall & 0.70 & 0.50 & 0.50 & 0.50 \\
\hline$\neg$ window/wall & 0.25 & 0.10 & 0.10 & 0.10 \\
\hline $\begin{array}{l}\text { Internal heat gains (heat from inhabitants, } \\
\text { appliances, equipment, and lighting) }\end{array}$ & $4.0 \mathrm{~W} / \mathrm{m}^{2}$ & & & \\
\hline Ventilation (air change rate) & 0.94 ach & 0.86 ach & 0.86 ach & 0.86 ach \\
\hline Heating system type and efficiency & Radiator (1.0) & Radiator (1.0) & HVAC (3.8) & HVAC (3.8) \\
\hline Cooling system type and efficiency & HVAC system (3.0) & HVAC system (3.0) & HVAC system (5.1) & HVAC system (5.1) \\
\hline DHW preparation system type and efficiency & Natural gas heater $(0.89)$ & $\begin{array}{l}\text { Solar thermal collectors } \\
\text { and natural gas heater }(0.89)\end{array}$ & $\begin{array}{l}\text { Solar thermal collectors } \\
\text { and new natural heat pump (4.3) }\end{array}$ & $\begin{array}{l}\text { Solar thermal collectors } \\
\text { and new natural heat } \\
\text { pump ( } 4.3)\end{array}$ \\
\hline Renewable energy sources & & - & & \\
\hline Solar collectors for DHW, $\mathrm{m}^{2}$ & - & 2.60 & 2.79 & 2.79 \\
\hline Solar panels for electricity production, $\mathrm{m}^{2}$ & - & - & 0 & 12.9 \\
\hline
\end{tabular}

natural gas, biomass and thermal energy from solar systems. For the calculation of the non-renewable primary energy, the contribution of the on-site renewable energy systems (solar thermal, photovoltaic) is deducted from the total amount of primary energy use, which is according to Portuguese regulation. In the results, values per $\mathrm{m}^{2}$ refer to the acclimatized net floor area.

\subsection{Assessment of the life cycle costs}

The costs of the renovation scenarios and the related maintenance costs were estimated based on market surveys. The energy costs are based on Portuguese energy prices and the estimation of the evolution of the energy prices for the calculation period follows the scenario given by the Guidelines accompanying Commission Delegated Regulation (EU) N. ${ }^{\circ}$ 244/2012 [41].

The average prices of energy (VAT included) considered were $0.22 € / \mathrm{kWh}$ for the electricity bought from the grid and 0.08 $€ / \mathrm{kWh}$ for natural gas. The selling price of the surplus energy exported to the grid is $0.055 € / \mathrm{kWh}$, according to the Portuguese context [42].

The global costs of each of the retrofit scenarios defined previously refer to the net present value (NPV) of the capital costs for the initial retrofit works and replacements during the considered period of 30 years, the maintenance costs and the energy costs, with a discount rate of $3 \%$. In all the renovation scenarios, materials, workmanship and maintenance costs were considered. The lifetime and the annual preventive maintenance including operation, repair and servicing costs in \% of the initial investment of the systems defined in the EN 15459:2007 [43] standard were considered. The radiators, fan coils, gas heater, HVAC systems, heat pump and solar thermal systems were replaced after 20 years and the PV system after 25 years (in accordance with manufacturers' warranties).

The costs considered in the Maintenance scenario are the repair of cracks and the cleaning and painting of the facade. Additionally, the radiators and fan coils and the gas heater were also replaced with equivalent ones.

In the Basic renovation, the costs considered are the costs of the materials and workmanship of the renovation works (repair of cracks, cleaning the facade, application of the ETICS on the façade, application of the insulation on the roof and garage's ceiling, replacement of the roof tiles and of the windows, including the installation of shading systems), and the systems and fittings (radiators, cooling system, gas heater, storage tank and flat plate solar thermal collectors).

In the Cost-optimal and Zero Energy renovation, the costs of the materials and workmanship of the renovation works considered are the same as in the Basic scenario, and for the systems and fittings includes the costs of the heat pump, HVAC systems, storage tank and vacuum tubes solar thermal collector. Additionally, the Zero Energy scenario includes the costs of a PV system.

\subsection{Assessment of the environmental performance}

The assessment of the environmental performance comprises the analysis of the input and output of materials, energy consumption and emissions to the environment of a product over its life cycle and therefore is based on the life cycle inventory. The used life cycle assessment approach is based on EN15978:2011 [37], and according to this standard the results from the assessment of the environmental performance are expressed as indicators that represent the quantified environmental impacts and aspects caused by the building during its whole life cycle. This standard states that the assessment of the environmental performance of a building is based on 22 indicators, subdivided into the following four types: i) indicators describing environmental impacts ( 7 indicators); ii) indicators describing resource use (8); iii) indicators describing waste categories (3); and iv) indicators describing the output flows leaving system (4).

Analysing the current state-of-art in the field of life cycle analysis of design alternatives at the buildings scale (e.g. Refs. [44,45,33]), building components (e.g. Refs. [46,47]) or building technical systems (e.g. Refs. $[17,24,48]$ ) it is possible to verify that for practical reasons most studies consider a limited set of indicators in the analysis rather than considering the complete list of the EN15978:2011 [37] environmental indicators.

Since this research is focused on the comparative analysis of the potential environmental impacts resulting from each energy renovation scenario, only type 1 group of indicators of this standard were considered. According to the EN 15978:2011 [37], the impact assessment should involve seven midpoint environmental impact 
categories: global warming, ozone depletion, acidification of soil and water, eutrophication, photochemical ozone creation and depletion of abiotic resources (elements and fossil, separately). These environmental impact categories were assessed using the characterization factors of the CML-IA [49] life cycle impact assessment method (developed in the Netherlands by the Institute of Environmental Sciences (CML) of Leiden University).

In addition to these indicators, two additional environmental categories are considered (Table 2). These categories are calculated based on a single-issue method, the Cumulative Energy Demand (CED) [50]. This method expresses the depletion of energy resources based on the higher heating value and, in fact this provides the calculation of six environmental categories [51] (non-renewable, fossil; non-renewable, nuclear; non-renewable, biomass; renewable, biomass; renewable, wind, solar, geothermal; renewable, water) which were grouped and presented in a simplified form in only two categories with the same unit (megajoule - MJ): Non-renewable Cumulative Energy Demand $\left(\mathrm{CED}_{\mathrm{NRE}}\right)$ and Total Cumulative Energy Demand ( $\mathrm{CED}_{\mathrm{TOT}}$ ). According to several authors (e.g. Ref. [34]) these two indicators that describe the life cycle energy consumption are of utmost importance in the comparison between different energy targets in building renovation.

To ease the quantification process, a life cycle analysis software (SimaPro 8.3) was used to modulate the life cycle of the analysed renovation scenarios and to assess the abovementioned life cycle impact categories.

Table 2 presents the LCA method and the declared unit that was used to quantify the environmental indicators.

\section{Presentation and analysis of results}

\subsection{Energy performance}

The results of the energy simulations carried out for the four different scenarios are presented in Table 3. From the analysis of Table 3 it is possible to verify that, compared to the before renovation (Maintenance scenario), the reduction in the primary energy consumption is around $60 \%, 89 \%$ and $91 \%$ for the Basic, Costoptimal and Zero Energy renovation, respectively. The reduction in the primary energy consumption of the Cost-optimal renovation compared to the Basic renovation scenario is around $73 \%$ and for the Zero Energy scenario, the reduction is about $78 \%$.

The use of the solar thermal collectors in the Basic scenario allows a significant reduction (65\%) in the energy needs for DHW preparation and $79 \%$ in the Cost-optimal and Zero Energy scenarios. In the Zero Energy scenario, the PV system produces $1671 \mathrm{kWh} /$ year of electricity, that fulfils the building energy needs for heating, cooling and DHW preparation (backup system needs). As the PV system is connected to the electric grid, and since the production of the energy occurs during the day, the produced renewable electricity that is not directly consumed in the building is exported to this grid. This energy will compensate the energy that is bought from the grid, during night-time and when the energy produced by the PV system is insufficient for the building needs. The annual balance of the electricity produced on-site has a surplus of $67.12 \mathrm{kWh} /$ year.

\subsection{Life cycle costs}

The initial costs of the renovation (costs of the envelope renovation and systems) and of the replacement of the systems at the end of their lifetime (25 years for the PVs and 20 for the other systems) are high. Therefore, it is important to analyse, for each renovation scenario, the evolution of the lifetime cumulative costs (Fig. 1). As presented in Fig. 1, the Cost-optimal renovation has the shorter payback time, about 9 years. Zero Energy renovation scenario payback time is around 10 years, approximately half of the lifetime of the systems installed. The Basic renovation scenario payback time is about 11 years. Analysing Fig. 1 it is also possible to understand that the contribution of renovation works and systems acquisition (year 0 ) in the overall lifetime costs is significant, as well as the replacement of the systems (years 20 and 25), especially in Cost-optimal and Zero Energy renovation scenarios. It is also possible to see the reduced effect of the PV system cost in the Zero Energy renovation scenario when compared with the Cost-optimal scenario.

These results show that regarding the lifetime costs, the Costoptimal and Zero Energy renovations are cost-effective and that the acquisition and the replacement costs of the systems are amortized before the end of the renovation lifetime ( 30 years). The Cost-optimal renovation scenario is the one with the best economic performance.

Since in a residential building the period of the production of energy from a PV system (daytime) is mismatched to a period of higher consumption (night), most of the energy produced on-site is exported to the energy grid. As the price of energy sold to the grid is substantially lower than the acquisition price $(0.055 € / \mathrm{kWh}$ instead of $0.22 € / \mathrm{kWh}$ ) the PV system itself is not economically attractive.

\subsection{Environmental performance}

Table 4 presents for each renovation scenario the building products inputs related to the construction works of each renovation scenario.

Table 5 presents, for each renovation scenario, the annual equivalent lifecycle impacts, and the potential improvements compared to the performance of the existing building (Maintenance). As recommended by the EN 15978:2011 [37], for the Zero Energy scenario, Table 5 presents separately the benefits resulting from the electricity produced in the PV panels as "benefits outside the system boundary". The reasoning for this is that PV panels are connected to the public electricity grid and $100 \%$ of the produced renewable electricity is exported to this network. Nevertheless, these benefits are deducted from the lifetime inside boundary's

\section{Table 2}

LCA method and declared unit that was used to quantify the environmental indicators.

\begin{tabular}{|c|c|c|}
\hline Indicators & Units & Methods \\
\hline Global warming potential (GWP) & [ $\mathrm{Kg} \mathrm{CO}_{2}$ equiv.] & CML-IA baseline (v3.02) \\
\hline Depletion of the stratospheric ozone layer (ODP) & [KgCFC-11 equiv.] & CML-IA baseline (v3.02) \\
\hline Acidification potential (AP) & [ $\mathrm{Kg} \mathrm{SO}_{2}$ equiv.] & CML-IA baseline (v3.02) \\
\hline Eutrophication potential (EP) & [Kg $\mathrm{PO}_{4}$ equiv.] & CML-IA baseline (v3.02) \\
\hline Formation potential of tropospheric ozone (POCP) & [Kg C $\mathrm{K}_{2} \mathrm{H}_{4}$ equiv.] & CML-IA baseline (v3.02) \\
\hline Abiotic depletion potential of fossil resources (ADP_FF) & [MJ equiv.] & CML-IA baseline (v3.02) \\
\hline Depletion of abiotic resources-elements (ADP_elements) & [kg.SB equiv.] & CML-IA baseline (v3.02) \\
\hline Cumulative Energy Demand - non renewable $\left(\mathrm{CED}_{\mathrm{NRE}}\right)$ & [MJ equiv.] & Cumulative Energy Demand (v1.09) \\
\hline Cumulative Energy Demand - total (CED $\left.\mathrm{COTAL}_{\mathrm{TO}}\right)$ & [MJ equiv.] & Cumulative Energy Demand (v1.09) \\
\hline
\end{tabular}


Table 3

Results of energy simulations for the different scenarios.

\begin{tabular}{|c|c|c|c|c|}
\hline Properties of building & Before renovation (Maintenance) & $\begin{array}{l}\text { Basic renovation } \\
\text { (minimum legal requirements) }\end{array}$ & Cost-optimal renovation & Zero Energy renovation \\
\hline \multicolumn{5}{|c|}{ Building's energy needs (net energy, without system losses), $\mathrm{kWh} /\left(\mathrm{m}^{2} \cdot\right.$ year) } \\
\hline Space heating & 134.52 & 54.14 & 54.14 & 54.14 \\
\hline Space cooling & 9.19 & 7.05 & 7.05 & 7.05 \\
\hline Domestic hot water & 23.77 & 23.77 & 21.40 & 21.40 \\
\hline \multicolumn{5}{|c|}{ Delivered energy (energy use of technical systems with systems losses) net energy, $\mathrm{kWh} /\left(\mathrm{m}^{2} \cdot\right.$ year) } \\
\hline Space heating & 134.52 & 54.14 & 14.25 & 14.25 \\
\hline Space cooling & 3.06 & 2.53 & 1.38 & 1.38 \\
\hline Domestic hot water & 26.71 & 7.76 & 0.41 & 0.41 \\
\hline \multicolumn{5}{|l|}{ Produced energy on site, $\mathrm{kWh} /\left(\mathrm{m}^{2} \cdot\right.$ year $)$} \\
\hline Solar collectors (heat) & 0.00 & 14.49 & 19.54 & 19.54 \\
\hline PV panels (electricity) & 0.00 & 0.00 & 0.00 & $16.71^{\mathrm{a}}$ \\
\hline \multicolumn{5}{|l|}{ Primary energy use, $\mathrm{kWh}_{\mathrm{PE}} /\left(\mathrm{m}^{2} \cdot\right.$ year $)$} \\
\hline Energy performance value, $\mathrm{kWh} /\left(\mathrm{m}^{2} \cdot\right.$ year $)$ & 370.67 & 149.45 & 40.10 & 0.00 \\
\hline
\end{tabular}

a The PV system produces annually $1671 \mathrm{kWh}, 289 \mathrm{kWh} / \mathrm{year}$ are used on-site and the remaining $1382 \mathrm{kWh} / \mathrm{year}$ are exported to the electric grid.

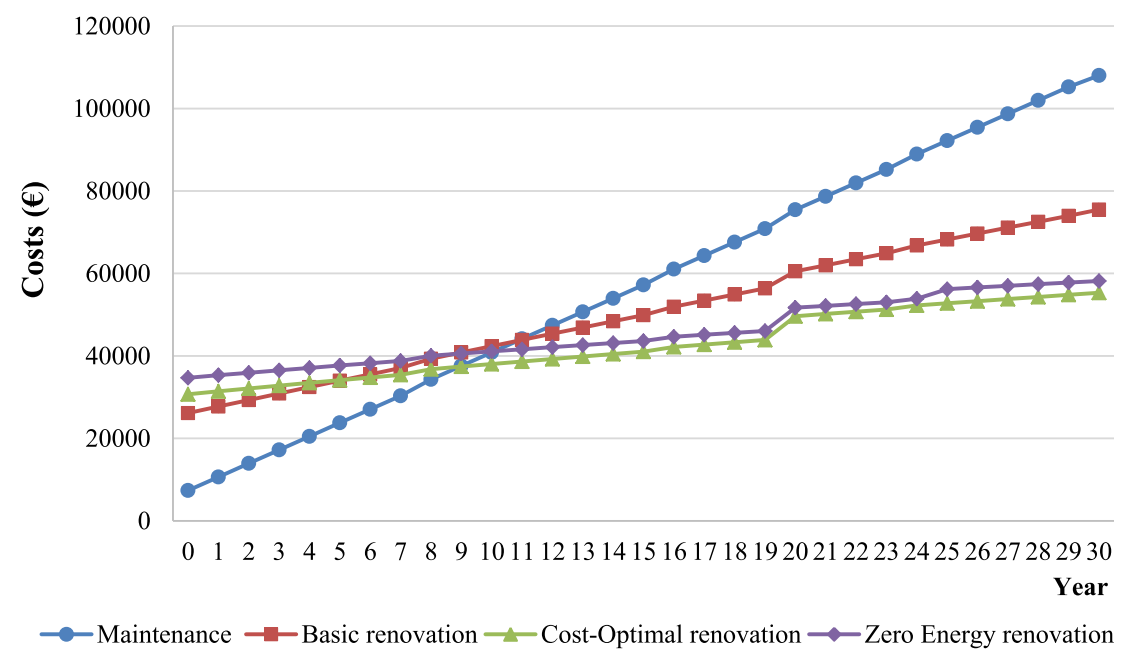

Fig. 1. Lifetime cumulative energy costs of each renovation scenario.

Table 4

Inventory of used building products.

\begin{tabular}{|c|c|c|c|c|}
\hline Inventory item & $\begin{array}{l}\text { Before renovation } \\
\text { (Maintenance) }\end{array}$ & $\begin{array}{l}\text { Basic renovation } \\
\text { (fulfils minimum } \\
\text { legal requirements) }\end{array}$ & Cost-optimal renovation & Zero Energy renovation \\
\hline \multicolumn{5}{|l|}{ Lifetime material input ( $\mathrm{kg}$ ) } \\
\hline Cement mortar & & 1900.00 & 1900.00 & 1900.00 \\
\hline Ceramic tile & & 4375.00 & 4375.00 & 4375.00 \\
\hline Expanded extruded polystyrene (XPS) & - & 686.72 & 686.72 & 686.72 \\
\hline Synthetic mortar & - & 4786.20 & 4786.20 & 4786.20 \\
\hline Water-based paint & 164.16 & 164.16 & 164.16 & 164.16 \\
\hline \multicolumn{5}{|l|}{ Lifetime windows renovation $\left(\mathrm{m}^{2}\right)$} \\
\hline $\begin{array}{l}\text { PVC windows with double glazed glass, } \\
\text { including shading devices (PVC shutters) }\end{array}$ & - & 15.00 & 15.00 & 15.00 \\
\hline
\end{tabular}

impacts in order to allow comparisons with the other scenarios.

From the analysis of Tables 3 and 5, it is possible to conclude that the lower the energy consumption of a renovation scenario is the better is the environmental performance. Since the goal of the Costoptimal scenario was to reduce in $80 \%$ the primary energy needs of the existing building (before renovation), results show good correlation between the reduction of energy needs and the reduction of the overall potential environmental impacts. These results also highlight that the contribution of the energy-related impacts in the overall potential environmental life cycle impacts is much higher when compared with the contribution of the building integrated energy systems and embodied impacts of building products. This means that the thermal retrofitting of building envelopes together with the integration of solar systems (STC and PV) is a good principle to significantly reduce the life cycle impacts of a building.

According to several authors (e.g Refs. [47,52,53]) the environmental impact category that most influences the overall environmental performance is the Global Warming Potential (GWP). Therefore, it is relevant to analyse, for each renovation scenario, the evolution of this impact category along the considered lifetime 
Table 5

Annual equivalent life cycle impacts per net floor area and potential improvements resulting from each renovation scenario.

\begin{tabular}{|c|c|c|c|c|c|c|c|c|c|}
\hline \multirow[t]{2}{*}{$\begin{array}{l}\text { Environmental } \\
\text { indicator }\end{array}$} & \multirow{2}{*}{$\begin{array}{l}\text { Before renovation } \\
\text { (Maintenance) } \\
\text { Impacts } \\
\text { (/m².year) }\end{array}$} & \multicolumn{2}{|c|}{$\begin{array}{l}\text { Basic renovation (fulfils } \\
\text { minimum legal } \\
\text { requirements) }\end{array}$} & \multicolumn{2}{|c|}{ Cost-optimal renovation } & \multicolumn{4}{|c|}{ Zero Energy renovation } \\
\hline & & $\begin{array}{l}\text { Impacts } \\
\left(/ \mathrm{m}^{2} \text {.year }\right)\end{array}$ & Improvement(\%) & $\begin{array}{l}\text { Impacts } \\
\left(/ \mathrm{m}^{2} \text {.year }\right)\end{array}$ & Improvement(\%) & $\begin{array}{l}\text { Impacts of the } \\
\text { considered } \\
\text { boundary } \\
\left(/ \mathrm{m}^{2} \text {.year }\right)\end{array}$ & $\begin{array}{l}\text { Benefits outside the } \\
\text { system boundary }\end{array}$ & $\begin{array}{l}\text { Overall } \\
\text { impacts } \\
\left(/ \mathrm{m}^{2} \text {.year }\right)\end{array}$ & Improvement(\%) \\
\hline ADP_elements & $1,62 \mathrm{E}-02$ & $1,41 \mathrm{E}-02$ & $13 \%$ & $1,04 \mathrm{E}-02$ & $35 \%$ & $1,47 \mathrm{E}-02$ & $1,27 \mathrm{E}-03$ & $1,34 \mathrm{E}-02$ & $17 \%$ \\
\hline ADP_FF & $1,20 \mathrm{E}+05$ & $5,96 \mathrm{E}+04$ & $50 \%$ & $1,84 \mathrm{E}+04$ & $85 \%$ & $1,94 \mathrm{E}+04$ & $1,30 \mathrm{E}+04$ & $6,40 \mathrm{E}+03$ & $95 \%$ \\
\hline GWP100a & $9,06 \mathrm{E}+03$ & $4,63 \mathrm{E}+03$ & $49 \%$ & $1,46 \mathrm{E}+03$ & $84 \%$ & $1,54 \mathrm{E}+03$ & $9,93 E+02$ & $5,52 \mathrm{E}+02$ & $94 \%$ \\
\hline ODP & $2,78 \mathrm{E}-03$ & 1,39E-03 & $50 \%$ & $2,24 \mathrm{E}-03$ & $19 \%$ & $2,26 \mathrm{E}-03$ & $7,14 \mathrm{E}-05$ & 2,19E-03 & $21 \%$ \\
\hline POCP & $2,83 \mathrm{E}+00$ & $1,44 \mathrm{E}+00$ & $49 \%$ & $4,65 \mathrm{E}-01$ & $84 \%$ & $4,98 \mathrm{E}-01$ & $3,17 \mathrm{E}-01$ & $1,81 \mathrm{E}-01$ & $94 \%$ \\
\hline $\mathrm{AP}$ & $6,82 \mathrm{E}+01$ & $3,33 \mathrm{E}+01$ & $51 \%$ & $1,01 \mathrm{E}+01$ & $85 \%$ & $1,08 \mathrm{E}+01$ & $7,85 \mathrm{E}+00$ & $2,92 \mathrm{E}+00$ & $96 \%$ \\
\hline EP & $1,71 \mathrm{E}+01$ & $8,78 \mathrm{E}+00$ & $49 \%$ & $3,05 \mathrm{E}+00$ & $82 \%$ & $3,43 E+00$ & $1,97 \mathrm{E}+00$ & $1,46 \mathrm{E}+00$ & $91 \%$ \\
\hline CED_NRE & $1,29 \mathrm{E}+05$ & $6,46 \mathrm{E}+04$ & $50 \%$ & $2,02 \mathrm{E}+04$ & $84 \%$ & $2,14 \mathrm{E}+04$ & $1,41 \mathrm{E}+04$ & $7,38 \mathrm{E}+03$ & $94 \%$ \\
\hline CED_TOT & $1,52 \mathrm{E}+05$ & $7,61 \mathrm{E}+04$ & $50 \%$ & $2,34 \mathrm{E}+04$ & $85 \%$ & $2,48 \mathrm{E}+04$ & $1,69 \mathrm{E}+04$ & $7,90 \mathrm{E}+03$ & $95 \%$ \\
\hline
\end{tabular}

(Fig. 2).

From the analysis of Fig. 2, it is possible to understand that the contribution of the renovation works (year 0 ) in the overall lifecycle impacts is very low. It is also possible to see the reduced effect of replacing the STC systems in the three renovation scenarios (year 20) and the effect of replacing the PV system in the Zero Energy scenario (year 25). Due to the avoided $\mathrm{CO}_{2}$ emissions related to the production of renewable electricity in the PV panels considered in the Zero Energy scenario, it is possible to see the slight decrease of the accumulated GWP along the considered lifetime. Compared with the before renovation scenario (Maintenance), the emissions saved in the lifetime are 129 ton. $\mathrm{CO}_{2}$ eq. 220 ton. $\mathrm{CO}_{2}$ eq. and 244 ton. $\mathrm{CO}_{2}$ eq. for the Basic, Cost-optimal and Zero Energy scenario, respectively. Additionally, it is possible to conclude that the Greenhouse Emissions Payback Time (GPBT) of each scenario is around 3 years for the Basic scenario, and 2 years for both the Costoptimal and Zero Energy scenario.

Fig. 3 shows the lifetime Cumulative Energy Demand (total) $\mathrm{CED}_{\mathrm{TOT}}$ - of the four renovation scenarios. The $\mathrm{CED}_{\mathrm{TOT}}$ considers both the renewable and non-renewable embodied energy in the building products and energy systems used and the delivered energy consumed for heating, cooling and DHW during the building operation phase. Only the delivered energy from the public electricity grid is considered, meaning that the renewable energy produced by the PV is not taken into account in the CED tionally, the $\mathrm{CED}_{\mathrm{TOT}}$ also includes maintenance and replacement of the building energy systems. Comparing Fig. 2 with Fig. 3, the results show good correlation with the $\mathrm{CO}_{2}$ cumulative emissions, showing the importance of the energy consumption in the potential environmental impacts. Compared with the before renovation scenario (Maintenance), the lifetime saved CED TOT $_{\text {is } 2245 \mathrm{GJ}}$ (623590 kWh), $3834 \mathrm{GJ} \quad(1064994 \mathrm{kWh})$ and $4203 \mathrm{GJ}$ (1167470 kWh), for the Basic, Cost-optimal and Zero Energy scenarios respectively. Additionally, it is possible to conclude that the energy payback time (EPBT) is around 2.4 years ( 29 months) for the Basic renovation scenario and 1.5 years (18 months) for the Costoptimal and Zero Energy scenario.

It is also possible to verify that, after 30 years, the reduction in the building's embodied energy, compared with the Maintenance scenario, is of $48 \%$ for the Basic scenario, $83 \%$ for the Cost-optimal renovation and $90 \%$ for the Zero Energy renovation scenario.

At the level of the used energy systems (STC and PV), it is also interesting to study both the embodied Greenhouse Gas Payback Time (GPBT) and embodied Energy Payback Time (EPBT). This is important to understand both the environmental and energy benefits of using solar systems. For this purpose, Figs. 4 and 5 present, respectively, the cumulative GWP and $\mathrm{CED}_{\text {TOT }}$ of each used solar system for a lifetime period of 20 years.

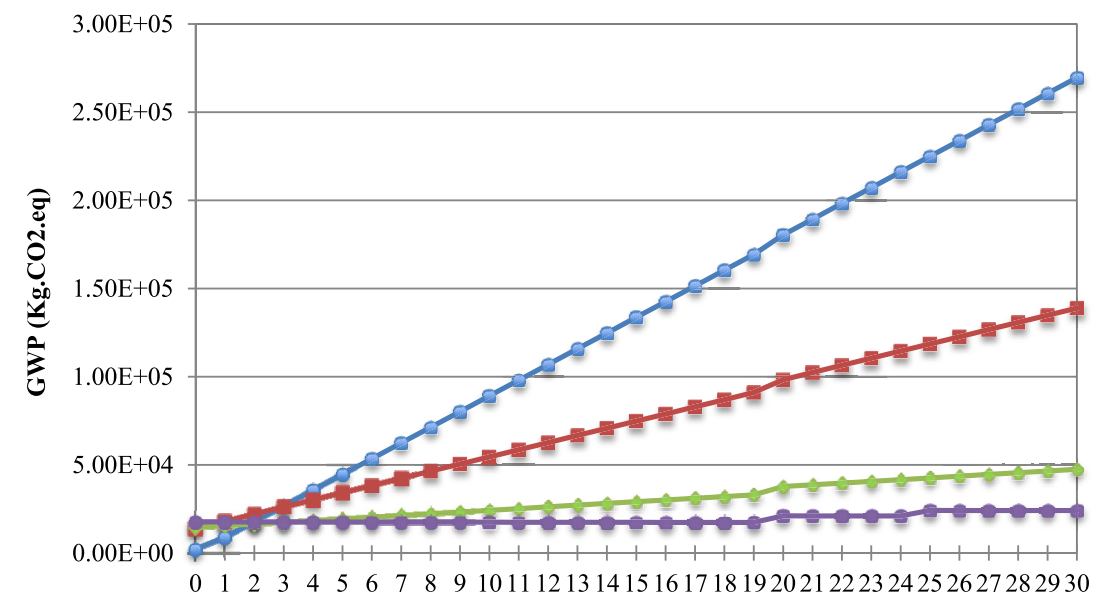

Year

$\multimap$ Maintenance $\longrightarrow$ Basic renovation $\multimap$ Cost-optimal Renovation $\longrightarrow$ Zero Energy Renovation

Fig. 2. Lifetime Cumulative Global Warming Potential (GWP) of each renovation scenario. 


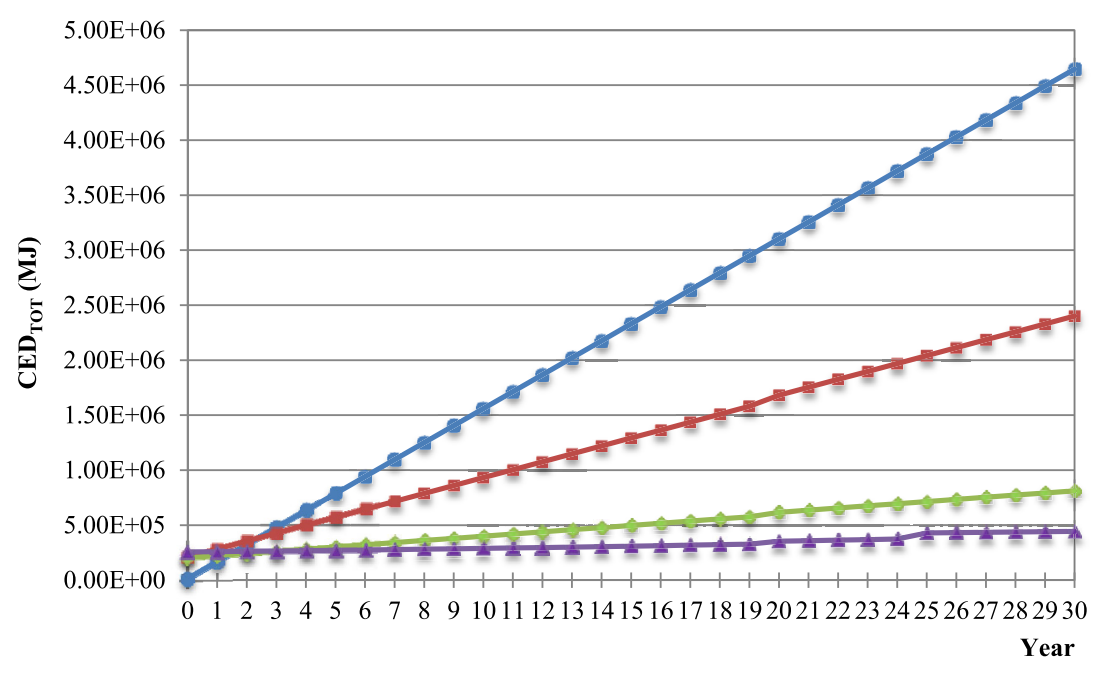

- Maintenance $\rightarrow$ Basic renovation $\leadsto$ Cost-optimal renovation $\rightarrow$ Zero Energy renovation

Fig. 3. Lifetime Cumulative Energy Demand (CEDTOT) of each renovation scenario.

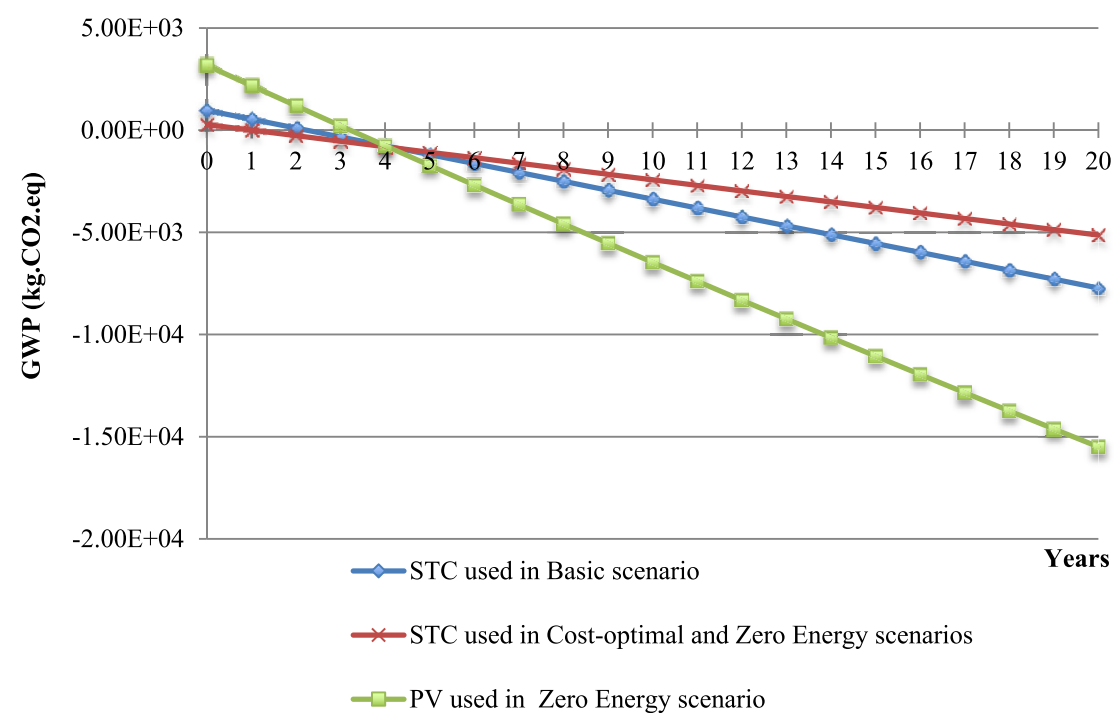

Fig. 4. Cumulative GWP of each used solar system for a lifetime period of 20 years.

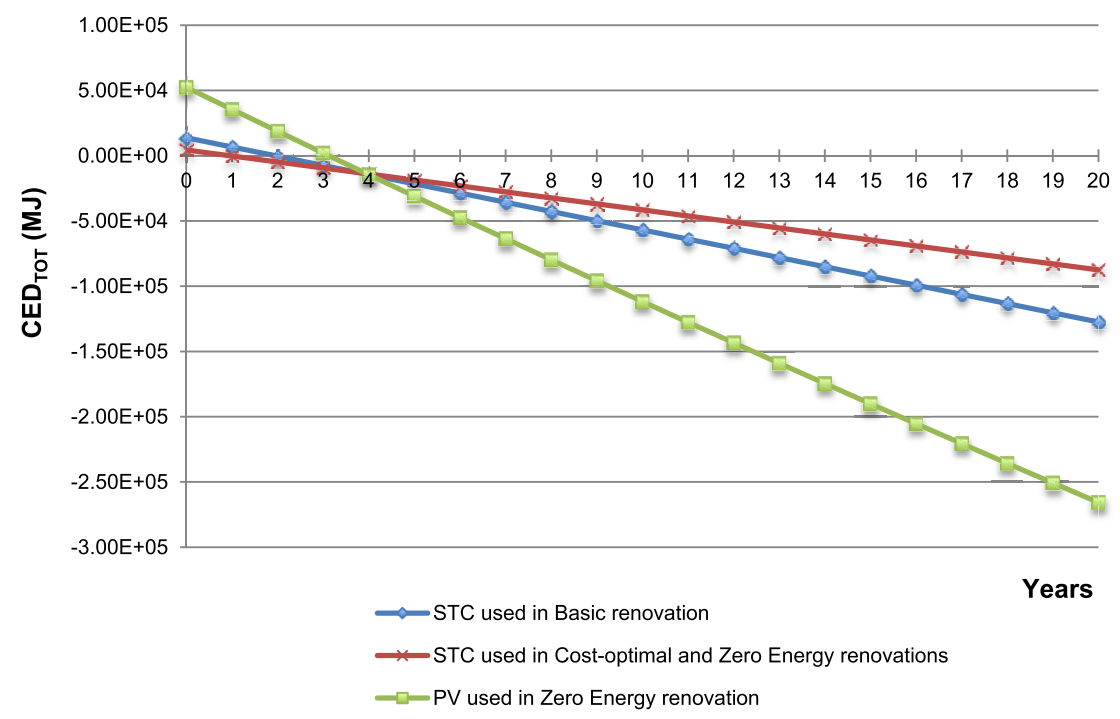

Fig. 5. Cumulative CEDTOT of each used solar system for a lifetime period of 20 years. 
The data presented for year 0 in Figs. 4 and 5 represent the embodied impacts related to the production and installation of the systems. In the case of the STC systems, the annual avoided $\mathrm{CO}_{2}$ emissions and saved CED natural gas consumption (conventionally used as a DHW backup system in Portugal) in the production of the domestic hot water. For the PV, the avoided emissions and saved CED considering that the amount of energy delivered by the PV system has equivalent $\mathrm{CO}_{2}$ emissions to the Portuguese energy mix. The energy produced by the PV system, including the energy exported outside the system boundary, compensates the use of energy from the public electricity grid. Therefore, all the energy produced by the PV system is considered in the analysis and has a negative contribution to the CED

From the analysis of Fig. 4, it is possible to conclude that the GPBT is around 2.24 years ( 27 months), for the STC system used in Basic renovation, and 1 year ( 12 months) for the STC system used in Cost-optimal and Zero Energy renovation. For the PV system used in Zero Energy renovation, the GPBT is of 3.22 years (39 months).

Regarding EPBT (Fig. 5) it is possible to conclude that is around 2 years (23 months), 0.95 years (12 months) and 3.12 years (38 months) in the case of STC system used in Basic renovation, STC system used in Cost-optimal and Zero Energy renovation and PV system used in Zero Energy renovation, respectively. Regarding the results obtained for the STCs, they are in line with the results of other international studies. For example, Kalogirou [26] investigated a domestic, thermosiphon solar water heater (for the climate conditions of Nicosia, Cyprus) and concluded that the energy spent for manufacture/installation was recouped in approximately 13 months. At the level of PVs, for example, Lu [54] studied the sustainability of a roof-mounted $22 \mathrm{~kW}$ building integrated PV system in Hong Kong and concluded a GPBT ranging from 3.6 to 5.3 years (depending on the considered energy mix) and an EPBT of 7.3 years.

\section{Conclusions}

This paper studied four renovation scenarios (Maintenance, Basic, Cost-optimal and Zero Energy) for a detached single-family building, considering the climate of Porto, Portugal. The building is representative of $44.5 \%$ of the Portuguese residential building stock and characterises the buildings built between 1961 and 1990.

For each renovation scenario, the economic payback time and greenhouse emissions payback time for the materials and systems used were assessed. To study the efficiency of each renovation scenario this paper calculated the lifetime costs and energy consumption using the Portuguese thermal regulation methodology. Additionally, the payback times of the renewable energy systems were also estimated.

The Basic renovation (minimum requirements to fulfil the national thermal regulation) allows a $60 \%$ reduction and the Costoptimal renovation results in an $89 \%$ reduction in the annual energy needs compared to the Maintenance scenario. The main differences in the renovation costs of each scenario are due to the systems considered (HVAC, STC, and PV).

The Cost-optimal renovation scenario is the one with the shorter payback time, 9 years, even with a $75 \%$ increase in the renovation costs comparing with the Maintenance scenario. The Zero Energy scenario, with a $78 \%$ increase in the renovation costs, comparing with the Maintenance scenario, has a payback time of 10 years. The renovation costs of the Basic scenario are 69\% higher than the Maintenance renovation costs, and the payback time is 11 years. The renovation works and the acquisition of systems (year 0 ) have a significant impact on the costs, especially in Cost-optimal and Zero Energy renovation scenarios. The PV system cost in the Zero Energy renovation scenario has a small impact on the overall cost when compared with the Cost-optimal scenario (12\% increase).

These results show that considering the lifetime costs, the Costoptimal and Zero Energy renovations are cost-effective and that the acquisition and the replacement of the HVAC systems, STC and PV systems and gas heater are both amortized before the end of the renovation lifetime (30 years). As expected from the analysis of results from previous studies [4], the Cost-optimal renovation scenario is the one with the best economic performance.

The contribution of renovation works (year 0 ) in the overall lifecycle impacts is very low and the replacement of the STC systems in the three renovation scenarios (year 20) and of the PV system in the Zero Energy scenario (year 25) has a reduced impact on the Lifetime Cumulative Global Warming Potential. The Greenhouse Emissions Payback Time of each renovation scenario is around 3 years for the Basic scenario and about 2 years for both the Cost-optimal and Zero Energy scenarios.

This study shows that a great amount of energy and greenhouse emissions are avoided for every renovation scenario during the considered lifetime (30 years) and that the Cost-optimal and Zero Energy scenarios are financially feasible, with payback times in the considered lifetime for the renovated building and lower than the payback time of the Basic renovation scenario.

The energy payback time is around 2.4 years for the Basic renovation scenario and 1.5 years for the Cost-optimal and Zero Energy scenario. The reduction in the building's Cumulative Energy Demand energy (considering a 30 life cycle), is of $48 \%$ for the Basic scenario, $83 \%$ for the Cost-optimal renovation and $90 \%$ for the Zero Energy renovation scenario when compared with the Maintenance only scenario.

The embodied Greenhouse Gas Payback Time is around 2.24 years for the STC system used in Basic renovation, and 1 year for the STC system used in Cost-optimal and Zero Energy renovation. For the PV system used in Zero Energy renovation, the embodied Greenhouse Gas Payback Time is 3.22 years. The embodied Energy Payback Time is around 2 years, 0.95 years and 3.12 years in the case of STC system used in Basic renovation, STC system used in Cost-optimal and Zero Energy renovation and PV system used in Zero Energy renovation, respectively.

As presented above, the PV system implemented in the Zero Energy renovation is connected to the public electricity grid and no battery banks are used to store the surplus energy produced all over the day. Analysing the market, it is possible to verify that there are already several types of batteries to be associated to PV systems, from more standard technologies, in terms of price and quality (e.g. $\mathrm{OPzV}$ - from the German "Ortsfeste Panzerplatte Verschlossen, OPzS from the German "Ortsfeste Panzerplatte Spezial", AGM - "Absorbent Glass Mat", lead-acid and lithium), to other emerging technologies (e.g. Tesla Powerwall rechargeable lithium battery). Nevertheless, recent studies (e.g. Ref. [55]) concluded that although in an economic perspective the self-consumption of energy produced from PVs is already attractive, the energy storage is not a profitable solution, because battery investment is still too high, despite the cost reduction witnessed in recent years. Besides to the high initial costs, another barrier is the limited lifetime of the battery cells, around 7 years in the conventional systems (e.g. Ref. [55]), which means that, in average, the battery banks would be replaced four times during the 30 years lifetime of the renovated building. The use of batteries would have an impact both on the potential life cycle impacts and costs. For instance, if battery banks would be considered in the Zero Energy renovation scenario, the embodied environmental impact would be higher and consequently, the Greenhouse gas payback time would be extended. Additionally, the investment cost would be higher, due to the high cost of the battery banks, but during the operation stage it could result on economic benefits because instead of selling the surplus energy at the very 
low price of $0.055 € / \mathrm{kWh}$, that energy would be used to avoid buying energy from the electricity grid at a much higher cost.

The payback times presented in this study were calculated using the energy needs obtained through the application of the method defined by the Portuguese thermal regulation. This method considers reference conditions, where the buildings are heated or cooled $24 \mathrm{~h}$ per day to maintain the indoor air temperature at $20^{\circ} \mathrm{C}$ or $25^{\circ} \mathrm{C}$ during the heating and cooling seasons, respectively. These reference conditions can be different from the real situation, which depends, among others, on the occupant's behaviour and effective annual climate conditions. This means that the real payback times may differ from the presented above. Nevertheless, in this type of study, where the goal is to compare different renovation scenarios, it is necessary to consider reference conditions, since it is impossible to know in advance the real situation.

In conclusion, this study shows that the considered scenarios for the implementation of the Cost-optimal and Zero Energy levels in Portuguese detached single-family residential buildings are costeffective while providing important potential environmental benefits during the lifetime of a renovation scenario (30 years). The energy prices variation and the discount rate might change the results of the analysis and, in some situations, the use of solar thermal and PV systems might not be adequate due to the shading of the surrounding buildings or an insufficient area to install the solar thermal and PV panels. In this situation, an alternative renewable energy source should be considered, depending on the location of the building.

\section{Acknowledgements}

The authors would like to acknowledge networking support by the COST Action TU1205 Building Integration of Solar Thermal Systems.

\section{References}

[1] J. José Vinagre Díaz, M. Richard Wilby, A. Belén Rodríguez Gonzales, Setting up GHG-based energy efficiency targets in buildings: the Ecolabel, Energy Pol. 59 (2013) 633-642.

[2] S. Vijayavenkataraman, S. Iniyan, R. Goic, A review of climate change, mitigation and adaptation, Renew. Sustain. Energy Rev. 16 (1) (2012) 878-897.

[3] T. Boermans, A. Hermelink, S. Schimschar, J. Grözinger, M. Offermann, K.E. Thomsen, J. Rose, S.O. Aggerholm, Principles for Nearly Zero-energy Buildings - Paving the Way to Effective Implementation of Policy Requirements, 2011.

[4] M. Ferreira, M. Almeida, A. Rodrigues, Cost optimality and net-zero energy in the renovation of Portuguese residential building stock - Rainha Dona Leonor neighbourhood case study, Int. J. Sustain. Build. Technol. Urban Dev. 5 (4) (Nov. 2014) 306-317.

[5] D INE, Inquérito ao Consumo de Energia no Sector Doméstico 2010, INE, DGEG, Lisbon, 2011.

[6] EPBD recast, EU-directive 2010/31/EU of the European Parliament and of the Council of 19 May 2010 on the Energy Performance of Buildings, 2010.

[7] EC, 2030 climate and Energy Goals for a Competitive, Secure and Low-carbon EU Economy, 2014 [Online]. Available, http://europa.eu/rapid/press-release_ IP-14-54_en.htm. (Accessed 5 December 2015).

[8] EC, in: A Policy Framework for Climate and Energy in the Period from 2020 to 2030-Communication from the Commission to the European Parliament, the Council, the European Economic and Social Committee and the Committee of the Regions, 2014.

[9] EC, COM(2011) 112 Final. A Roadmap for Moving to a Competitive Low Carbon Economy in 2050-Communication from the Commission to the European Parliament, the Council, the European Economic and Social Committee and the Committee of the Regions, 2011.

[10] F. Bartiaux, K. Gram-Hanssen, P. Fonseca, L. Ozoliņa, T.H. Christensen, A practice-theory approach to homeowners' energy retrofits in four European areas, Build. Res. Inf. 42 (4) (Apr. 2014) 525-538.

[11] European Commission, Strategy for the sustainable competitiveness of the construction sector and its enterprises, Brussels COM (2012) 26.

[12] S. Vilcekova, I. Selecka, E.K. Burdova, Sustainability assessment of family house, Energy Proc 96 (2016) 551-559.

[13] F. Ardente, G. Beccali, M. Cellura, V. Lo Brano, Life cycle assessment of a solar thermal collector: sensitivity analysis, energy and environmental balances, Renew. Energy (2005).
[14] R. Araya, F. Bustos, J. Contreras, A. Fuentes, Life-cycle savings for a flat-plate solar water collector plant in Chile, Renew. Energy (2017).

[15] J.F. Armendariz-Lopez, A. Luna-Leon, M.E. Gonzalez-Trevizo, A.P. ArenaGranados, G. Bojorquez-Morales, Life cycle cost of photovoltaic technologies in commercial buildings in Baja California, Mexico, Renew. Energy (2016).

[16] N. Arnaoutakis, M. Souliotis, S. Papaefthimiou, Comparative experimental Life Cycle Assessment of two commercial solar thermal devices for domestic applications, Renew. Energy (2017).

[17] L. Belussi, M. Mariotto, I. Meroni, C. Zevi, S.D. Svaldi, LCA study and testing of a photovoltaic ceramic tile prototype, Renew. Energy 74 (Feb. 2015) 263-270.

[18] G. Tsilingiridis, G. Martinopoulos, N. Kyriakis, Life cycle environmental impact of a thermosyphonic domestic solar hot water system in comparison with electrical and gas water heating, Renew. Energy (2004).

[19] DGEG, Despacho (extrato) n.o 15793-F/2013-Parâmetros para o Zonamento Climático. Direção-Geral de Energia e Geologia - Ministério do Ambiente Ordenamento do Território e Energia, 2013.

[20] Z.W. Zhong, B. Song, P.E. Loh, LCAs of a polycrystalline photovoltaic module and a wind turbine, Renew. Energy (2011).

[21] B. Esteban, J.R. Riba, G. Baquero, R. Puig, A. Rius, Environmental assessment of small-scale production of wood chips as a fuel for residential heating boilers, Renew. Energy (2014).

[22] L. Junghans, Evaluation of the economic and environmental feasibility of heat pump systems in residential buildings, with varying qualities of the building envelope, Renew. Energy (2015).

[23] A.J. Marszal, P. Heiselberg, R. Lund Jensen, J. Nørgaard, On-site or off-site renewable energy supply options? Life cycle cost analysis of a Net Zero Energy Building in Denmark, Renew. Energy (2012).

[24] C. Lamnatou, D. Chemisana, R. Mateus, M.G. Almeida, S.M. Silva, Review and perspectives on Life Cycle Analysis of solar technologies with emphasis on building-integrated solar thermal systems, Renew. Energy 75 (Mar. 2015) 833-846.

[25] A. Zahedi, Maximizing solar PV energy penetration using energy storage technology, Renew. Sustain. Energy Rev. 15 (1) (Jan. 2011) 866-870.

[26] S. Kalogirou, Thermal performance, economic and environmental life cycle analysis of thermosiphon solar water heaters, Sol. Energy 83 (1) (Jan. 2009) 39-48.

[27] V.V. Tyagi, N.A.A. Rahim, N.A. Rahim, J.A./L. Selvaraj, Progress in solar PV technology: research and achievement, Renew. Sustain. Energy Rev. 20 (Apr. 2013) 443-461.

[28] G.K. Singh, Solar power generation by PV (photovoltaic) technology: a review, Energy 53 (May 2013) 1-13.

[29] A. Badea, T. Baracu, C. Dinca, D. Tutica, R. Grigore, M. Anastasiu, A life-cycle cost analysis of the passive house 'POLITEHNICA' from Bucharest, Energy Build. 80 (Sep. 2014) 542-555.

[30] Portugal, Regulamento de Desempenho Energético dos Edifícios de Habitação [Portuguese Thermal Regulation]. Decreto-Lei no 118/2013 de 20 de Agosto, Portugal, 2013, 2013.

[31] M. Ferreira, M. Almeida, A. Rodrigues, Cost-optimal energy efficiency levels are the first step in achieving cost effective renovation in residential buildings with a nearly-zero energy target, Energy Build. 133 (Dec. 2016) 724-737.

[32] M. Ferreira, M. Almeida, A. Rodrigues, S.M. Silva, Comparing cost-optimal and net-zero energy targets in building retrofit, Build. Res. Inf. 44 (2) (Feb. 2016) $188-201$

[33] S.M. Silva, R. Mateus, L. Marques, M. Ramos, M. Almeida, Contribution of the solar systems to the nZEB and ZEB design concept in Portugal - energy, economics and environmental life cycle analysis, Sol. Energy Mater. Sol. Cells (Nov. 2016).

[34] M. Ferreira, M. Almeida, A. Rodrigues, S.M. Silva, Comparing cost-optimal and net-zero energy targets in building retrofit, Build. Res. Inf. (Nov. 2014) 1-14

[35] I. \& LNEC, Parque Habitacional e a sua Reabilitação - Análise e Evolução, 2013 [Online]. Available, http://www.ine.pt/xportal/xmain?xpid=INE\&xpgid=ine_ publicacoes\&PUBLICACOESpub_ boui $=165231362 \&$ PUBLICACOEStema $=00 \&$ PUBLICACOESmodo $=2$.

[36] MAOTE, Portaria n.o 349-B/2013, de 29 de novembro, 2013. Diário da República N.o 232, 1.a série.

[37] CEN, EN 15978:2011. Sustainability of Construction Works. Assessment of Environmental Performance of Buildings. Calculation Method, 2011.

[38] ISO, ISO 13790:2008-Energy Performance of Buildings - Calculation of Energy Use for Space Heating and Cooling, 2008. Geneva.

[39] DGEG, "SCE.ER.” Direção-Geral de Energia e Geologia (DGEG), 2016. Lisbon.

[40] JRC European Comission, Photovoltaic geographical information system (PVGIS), Jt. Res. Cent. - Inst. Energy Transp. (2017) 10.

[41] EC, Guidelines accompanying the commission delegated regulation (EU) No 244/2012 of 16 january 2012, supplementing directive 2010/31/EU of the european parliament and of the council on the energy performance of buildings, Off. J. Europe. Union C 115/1 (2012).

[42] MAOTE, Decreto-Lei n.153/2014. Regimes jurídicos aplicáveis à produção de eletricidade destinada ao autoconsumo e ao da Venda à rede elétrica de serviço público a partir de recursos renováveis, por intermédio de Unidades de Pequena Produção, 2014.

[43] CEN, EN 15459-Energy Performance of Buildings - Economic Evaluation Procedure for Energy Systems in Buildings, CEN - European Committee for Standardization, 2007.

[44] R. Mateus, L. Bragança, Sustainability assessment and rating of buildings: developing the methodology SBToolPT-H, Build. Environ. 46 (10) (Oct. 2011) 
$1962-1971$.

[45] A.F. Abd Rashid, S. Yusoff, A review of life cycle assessment method for building industry, Renew. Sustain. Energy Rev. 45 (May 2015) 244-248.

[46] N. Pargana, M.D. Pinheiro, J.D. Silvestre, J. de Brito, Comparative environmental life cycle assessment of thermal insulation materials of buildings, Energy Build. 82 (Oct. 2014) 466-481.

[47] R. Mateus, S. Neiva, L. Bragança, P. Mendonça, M. Macieira, Sustainability assessment of an innovative lightweight building technology for partition walls - comparison with conventional technologies, Build. Environ. 67 (Sep. 2013) 147-159.

[48] C. Lamnatou, G. Notton, D. Chemisana, C. Cristofari, The environmental performance of a building-integrated solar thermal collector, based on multiple approaches and life-cycle impact assessment methodologies, Build. Environ. 87 (May 2015) 45-58.

[49] UL-IES, “CML-IA Characterisation Factors - Software and Data - CML," CML-IA Characterisation Factors, 2012 [Online]. Available, http://cml.leiden.edu software/data-cmlia.html\#downloads.
[50] R. Frischknecht, N. Jungbluth, H.-J. Althaus, C. Bauer, G. Doka, R. Dones, R. Hischier, S. Hellweg, S. Humbert, T. Köllner, Y. Loerincik, M. Margni, T. Nemecek, Swiss Centre for Life Cycle Inventories Implementation of Life Cycle Impact Assessment Methods, 2007.

[51] H. Monteiro, F. Freire, Life-cycle assessment of a house with alternative exterior walls: comparison of three impact assessment methods, Energy Build. 47 (Apr. 2012) 572-583.

[52] R. Mateus, L. Bragança, Building Sustainability Assessment: System SBTool PT, 2010.

[53] Towards an Integrated Environmental Decision-making, EPA Science Advisory Board, Washigton, DC, 2000.

[54] L. Lu, H.X. Yang, Environmental payback time analysis of a roof-mounted building-integrated photovoltaic (BIPV) system in Hong Kong, Appl. Energy 87 (12) (Dec. 2010) 3625-3631.

[55] F.M. Camilo, R. Castro, M.E. Almeida, V.F. Pires, Economic assessment of residential PV systems with self-consumption and storage in Portugal, Sol. Energy 150 (Jul. 2017) 353-362. 